\title{
Evolução, macacos e homens da caverna nos anos 1920 norte-americanos
}

\author{
Evolution, monkeys, and cavemen in 1920s America
}

\author{
Henrique Rodrigues Caldeira \\ Universidade Federal de Minas Gerais. \\ henriquercaldeira@gmail.com
}

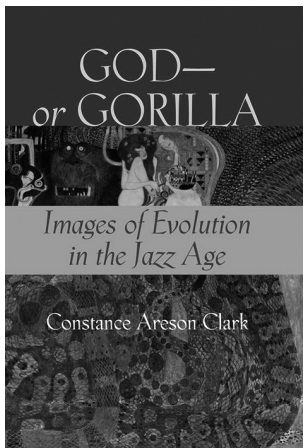

CLARK, Constance A. God - or Gorilla: images of evolution in the jazz age. Baltimore: JHU Press. 2008. 312p.

\begin{abstract}
Cod - or Gorilla: images of evolution in the jazz age é um livro

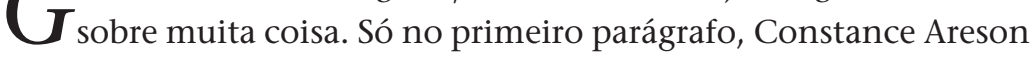
Clark, professora-associada de história da ciência e tecnologia no Worcester Polytechnic Institute, sinaliza pelo menos três grandes temas que pretende abordar. O primeiro, e mais importante, é o papel das imagens na produção e comunicação científica. O segundo, os esforços de demarcar a ciência em relação a outras formas de conhecimento. E o terceiro, o dilema das autoridades científicas entre o ideal de objetividade e neutralidade e a urgência social e institucional de posicionamento e atuação pública.

O contexto no qual a autora situa e enfrenta esses vastíssimos temas é o dos debates norte-americanos sobre a teoria da evolução nas primeiras décadas do século XX, um período que Clark chama de era do jazz, ainda que o jazz, em si, a manifestação artístico-musical,
\end{abstract} esteja completamente ausente da obra.

$\mathrm{O}$ argumento central desenvolvido ao longo das 312 páginas é o de que as imagens tiveram um papel fundamental em tais debates. A forma com que cada um "imaginava" a teoria da evolução, isto é, as imagens visuais presentes na cabeça de cada pessoa quando o tema da evolução era evocado, condicionou em boa medida a aceitação ou recusa de determinados aspectos da teoria, ou mesmo de sua totalidade.

Mais ainda, a autora argumenta que os próprios sujeitos dessa história tinham plena consciência da importância dessas imagens. Não por acaso, as principais investidas antievolucionistas direcionaram-se contra as imagens produzidas pelos evolucionistas. E esses, por sua vez, dedicaram-se a produzir e distribuir imagens em larga escala, fornecendo desde árvores filogenéticas até cenas da vida do homem no Paleolítico para professores, universidades, editoras, imprensa etc.

O paleontólogo Henry Fairfield Osborn (1857-1935), principal personagem da história narrada em God - or Gorilla, sintetiza esse empenho em produzir, distribuir e controlar 
as imagens da evolução. Atuando como diretor do American Museum of Natural History e aliado a grandes artistas, Osborn concentrou seus esforços em apresentar ao público imagens enobrecidas dos homens da caverna, o máximo possível distantes dos macacos e dos estereótipos de toga e porrete.

A atuação estratégica, ainda que sincera, de cientistas como Osborn, que objetivavam "redimir o caráter" de nossos ancestrais, isto é, adequá-los ao recato puritano de parte do público norte-americano, encontrou forte oposição tanto entre antievolucionistas quanto entre evolucionistas. Os primeiros questionavam principalmente a cientificidade das reconstituições de corpos, cenários e costumes pré-históricos, que, segundo eles, baseavamse em evidências insuficientes. Além disso, lideranças religiosas antievolucionistas viam na narrativa de progresso evolucionista uma falsa religião que ameaçava o verdadeiro cristianismo.

Do outro lado, alguns evolucionistas também questionavam a cientificidade das tentativas de conciliação entre as visões cristãs e evolucionistas de mundo. Afirmavam que, muitas vezes, dados que nos aproximavam de macacos ou do restante da natureza acabavam desconsiderados por simples preconceito ou soberba. Tal aversão à ideia de que fôssemos parentes próximos dos macacos recebeu até mesmo uma designação própria: pitecofobia (do grego pithekos, macaco).

God - or Gorilla é fartamente documentado e remete a uma bibliografia igualmente volumosa. As fontes reúnem filmes, livros de literatura, opúsculos de autoajuda, manuais e artigos científicos, obras antievolucionistas, colunas e charges de jornais e revistas, cartas pessoais de Osborn e registros do American Museum of Natural History, contudo, a expectativa criada pelo título e pela questão principal referente às imagens acaba sendo frustrada. Por alguma razão, talvez autoral, talvez editorial, pouquíssimas imagens estão de fato reproduzidas no livro. Em muitos casos, a autora apenas descreve brevemente as imagens ausentes ou menciona a sua localização - que muitas vezes são arquivos físicos de acesso restrito, como o arquivo pessoal de Osborn.

Mais decepcionante ainda é que mesmo as imagens reproduzidas no livro não recebem, na maioria das vezes, um tratamento analítico aprofundado e acabam servindo apenas como ilustrações de algum conteúdo previamente atestado em fontes textuais ou na bibliografia secundária. No final das contas, salvo algumas explorações originais sobre a personalidade de Osborn, o conteúdo do livro não traz grandes novidades à produção historiográfica existente sobre a controvérsia evolutiva nos EUA, especialmente quanto à relação entre ciência e religião (ver, por exemplo, Numbers, 2006; Larson, 2008; Bowler, 2009).

Um alento é o excelente capítulo 7 da obra, esse sim abundante em ilustrações que de fato fundamentam interpretações meticulosas e originais. Nesse capítulo, a autora explora a dinâmica das imagens no debate público, considerando as mensagens intencionais e não intencionais presentes em diagramas, reconstituições e modelos pretensamente objetivos. Na verdade, o que se verifica é uma complexa urdidura de evidências fósseis, teorias embriológicas, valores religiosos, discursos sobre raça, gênero e classe, ideais de cientificidade e anseios políticos.

Na maior parte da obra, contudo, o leitor acaba atingido apenas de raspão pela questão central apontada desde o título. O que de fato preenche os capítulos são boas análises da atuação de um pequeno número de evolucionistas e antievolucionistas - muito especialmente Henry Fairfield Osborn. A questão das imagens está sempre lá, mas um tanto embaraçada 
entre as demais estratégias utilizadas no debate, destacando-se apenas casualmente e de forma bastante repetitiva. Falta discussão teórica. Referências sobre estudo de imagens e representações na ciência estão em bom número nas notas bibliográficas, mas param por aí.

No fim das contas, God - or Gorilla: images of evolution in the jazz age é um bom livro. Apresenta um tema bastante interessante para os públicos acadêmico e geral e condensa com boa escrita uma vastíssima bibliografia sobre os debates públicos do início do século XX sobre o evolucionismo nos EUA. Definitivamente, não é o melhor título. Deus e gorila estão de fato bem representados no texto. As imagens da evolução, nem tanto. Do jazz então, nem se fala.

\section{REFERÊNCIAS}

BOWLER, Peter J.

Monkey trials and gorilla sermons: evolution and Christianity from Darwin to intelligent design. New York: Harvard University Press. 2009.

LARSON, Edward J.

Summer for the gods: the scopes trial and
America's continuing debate over science and religion. New York: Basic Books. 2008.

NUMBERS, Ronald L.

The creationists: from scientific creationism to intelligent design. New York: Harvard University Press. 2006.

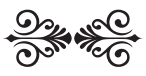

